\title{
Ways of encoding attention to the interlocutor in contemporary spoken Spanish
}

\author{
A proposal by Bert Cornillie (KU Leuven) and \\ Barbara De Cock (Université Catholique de Louvain).
}

\author{
Bert.cornillie@ arts.kuleuven.be \\ and \\ barbara.decock@uclouvain.be
}

In the Hispanic linguistic tradition, the argumentative structure of discourse has received a lot of attention from a monologic perspective (Portolés 1995; Montolío 2001; Domínguez García 2007). Yet, many recent studies in the field of the pragmatics of Spanish have shown considerable interest in the way speakers interact with interlocutors and in the kind of expressions fostered by this interaction (cf. the volumes edited by Martín Zorraquino and Montolío Durán 1998, Bustos Tovar et al. 2000, or by Márquez Reiter and Placencia 2004, to name but a few). The main objective of this special issue is to focus on a specific dimension of this interaction, namely the question how speakers express their attention to the interlocutor (or co-participant) linguistically. By focusing on the intersujectivity of the attention to the interlocutor (cf. infra), the proposed issue fills a gap in the Hispanic linguistic literature, which has been mainly concerned with the subjectivity of the speaker.

The analyses proposed in this volume focus on the different expression types that speakers use to accommodate (knowledge of) the interlocutor in different communicative contexts. Special attention is paid to the different levels of the utterance to which the expression types can belong (e.g. the difference between discourse markers and auxiliary verbs). All contributions in this proposal are corpus-based and hence offer an innovative view of different aspects of the discourse organization in contemporary Spanish.

Traditionally, speaker subjectivity has been interpreted as the speaker's attitude towards the proposition and has often been very prominent in modality studies. In such accounts, subjectivity is considered to be the speaker's evaluation or qualification of the possibility that the state of affairs expressed in the proposition has taken place, is taking place or will take place (cf. Nuyts 2001). This view works out relatively well for written language production or monologic spoken contexts, but corpus based analyses of interactive genres reveal that subjectivity involves many more dimensions in talk-in-interaction. It is now generally accepted that subjective markers have, in addition to their qualificational function, well recognized interactional, textual and rhetorical functions, such as persuading, manipulating, challenging, confronting, accepting, encouraging the flow of discussion and creating cohesive texts (Coates 1987; Kärkkäinen 2003; Simon-Vandenbergen \& Aijmer 2007; Englebretson 2007, Cornillie \& Pietrandrea 2012). In this volume, we want to focus on the role of expressions that take into account the hearer in talk-in-interaction and other contexts. Thus, we want to contribute to growing body of research based on a more dyadic view of language and cognition, on the one hand, and offer a series of linguistic analyses of Spanish phenomena, on the other.

Now, there are several ways of dealing with the dialogic nature of language. In literary and linguistic accounts inspired by Bakhtin (1987), analysts study formally monologic texts with a special eye for the heteroglossia or dialoguing voices. Applied to spoken language, the focus is then on the rich and diverse intertext present in the speaker's discourse, but the interaction between speech participants is not the main concern in this line of research. It is now established knowledge that speakers and authors often include shared world knowledge 
in their discourse. Within the framework of pragmatics, the topic of how speakers rely on general semantic and pragmatic principles to produce coherent discourse sequences has received due attention. In many studies, the discourse relation between bits of knowledge is referred to by means of inferential expressions, which involve subjective and objective logical operations such as induction or deduction, but also more creative types of reasoning such as abduction.

Argumentation-theoretical approaches to connectives have often been concerned with the internal relations between bits of discourse (cf. Pons Bordería 1998). In accounts of written discourse, connectives have mainly been dealt with from a monologic point of view. In spoken discourse a distinction has to be made between different spoken genres: the way a course lecture is structured is quite different from the turn-based structure of spontaneous conversation. It is in the latter type of spoken data where connectives get another meaning. Yet, as we will show, although connectives often express attention to the hearer's presupposition, they do not always refer to shared knowledge. Briz (1993: 159) presents several examples of connectives marking (dis)agreement. In (1) Speaker B, uses an adversative connective to express his disagreement with the positive intention of going to see a (good) movie, whereas in (2), Speaker B confirms the proposal made by Speaker A.

(1)

A. ¿Vienes al cine esta noche?

B. Pero si es un rollo.

(2)

A. Si quieres, lo puedes preguntar también

B. Pues sí

The pragmatic meanings in (1) and (2) do not refer to shared knowledge, but rather add new information to the speech situation so as to come to a more complete picture of the viewpoints of the speaker and the co-participant. That is, in these examples, the connectives do not hint at the co-participant's knowledge or stance. Rather the emphatic markers show that the speaker is somehow surprised that the co-participant did not have a complete view. In this special issue, we would like to offer a complementary view to talk-in-interaction by also focusing on how speakers refer to information held by the co-participant, which can but should not necessarily be shared. We think this is a challenging new line of research, which hooks up well with the existing body of research that deals with different aspects of intersubjectivity.

So far theoretical reflections on the conceptual dimensions of (inter)subjectivity have hardly been elaborated with a specific focus on Spanish, in spite of the popularity of the term in functional linguistics (see Traugott \& Dasher 2002, De Smet \& Verstraete 2006, and Athanasiadou, Canakis \& Cornillie 2006 for an overview, see also Scheibman 2002 for an extensive study of subjectivity in English). In the general linguistic literature, the expression of the reference to the addressee's subjectivity has been discussed from many different perspectives and has been accounted for in terms of stancetaking (Goffman 1981; Du Bois 2007), speech-act theory (Searle 1969, 1979; Givón 1990; König \& Siemund 2007), presupposition, the expression of subjectivity (Benveniste 1966; Lyons 1977; Traugott 1989; Traugott \& Dasher 2002) and intersubjectivity as an inherent dimension of human language (Lyons 1977; Traugott 1989; Verhagen 2005, 2008; cf. Zlatev et al. 2008).

With respect to intersubjectivity, the anthropological-linguistic literature has focused on the conceptualization of "multiple perspective" or "complex perspective" in grammar (Evans 2007, Berqvist \& San Roque 2012) and starts from concepts such as the "interaction engine" or "common ground" (Levinson \& Enfield 2006). A complex epistemic perspective 
can be defined as the speaker's assumptions regarding the status of information/experience as being either shared or non-shared between the speaker and the addressee. Intersubjectivity not only features the speaker's assumptions of the addressee's perspective but also simultaneously expresses the speaker's own perspective, which contrasts with subjective modal expressions and with grammatical markers that directly refer to the addressee's position.

Another view of intersubjectivity can be found in the framework of Conversation Analysis, which offers clear insights of how to pursue a strongly functional analysis of interaction. In this framework, intersubjectivity has been understood mainly in terms of explicit signs of a referential common ground (Schegloff 1992, Heritage 2007). This may surface in recognitionals management (Jefferson 1987) or the use of acknowledgement markers (Heritage 2005). This view is partially similar to the (inter)subjectivity concept in Benveniste (1966), as further developed by Traugott, among others. Yet, whereas Benveniste (and following) focuses on taking into account attitudes and beliefs of the speaker/hearer, CA focuses on explicit signs of the presence of a common ground, that is, a step further in the actual mutual understanding between speaker and hearer. Yet, CA-analysts do not differentiate between types of expressions and, by consequence, are less concerned with a grammatical analysis of the expressions and the level of the utterance they appear in.

Despite the vast literature on intersubjectivity, few studies (whether on Spanish or on other languages) have carried out a systematic data analysis of attention to the interlocutor. In English, intonation and syntactic variation such as topicalisation are used to signal speakerstance and the speaker's expectations on the knowledge-state of the addressee with regard to some state-of-affairs. A language such as German has a class of modal particles at its disposal to add complex epistemic perspective to the utterance. Several non-European languages have full-fledged paradigmatic sets of markers that parallel other well attested categories such as evidentiality and tense/aspect in marking knowledge status between the speech participants (e.g. Aikhenvald 2004). So far, Spanish studies have yet to account for the linguistic expressions that convey attention to the interlocutor. In the proposed volume we want to explore precisely the range of possibilities that Spanish offers in this respect.

\section{Major contributions}

- In the first place, the studies in this proposal are corpus-based and, as such, firmly anchored in real-life language use, as opposed to papers containing more theoretical discussions. Data mainly consist of authentic data in various interactive contexts, such as informal conversation, TV-debates, political debates, tertulias. This variety of corpora guarantees a very rich description of the attention to the interlocutor in Spanish.

Given that the analyses start from refined data analysis and not from theoretical assumptions, they uncover new domains of intersubjectivity, such as person referencing, spatial deixis and connectives. Thus, the analyses contribute to refining the conceptual structure of (inter)subjectivity and stance.

- Intersubjectivity is of course not the only concept relevant for the analysis of real-life (interactional) data. Indeed, several papers aim at incorporating in their analysis different theoretical approaches, with related concepts such as politeness, argumentation structure, attenuation, hedging. By doing so, the volume points out links between different theoretical approaches. It explicitly draws on previous studies in Spanish in context and other relevant publications in the field. 
- $\quad$ The papers offer new evidence for functional paths of linguistic change. The genesis of new expressions from perception to discourse or from spatial anchoring to epistemic stance as well as metonymic extensions in established expressions such as verbs and adverbs enrich previous accounts of modality, discourse markers and connectives in Spanish and beyond.

\section{Organization of the volume}

The papers deal with different expression types, which we structure as follows.

A first series of four papers is concerned with expressions related to the verb phrase. De Cock's paper addresses the role of person reference and depersonalization in indexing intersubjectivity in different interaction types. In Hennemann's contribution, the first person form of the cognition verb pensar is shown to have a hedging function as well as attenuation effects. In another paper, Hanegreefs \& González Melón deal with how grammaticalized perception verbs function as discourse markers indicating to which extent the perception is shared by speaker and interlocutor or imposed by the speaker on the interlocutor. Fuentes Rodríguez tackles the politeness and intensifying effects that formulaic expressions of afterthought bring about. The latter paper already announces the second series of papers concerning expressions with connective and adverbial properties. Rodríguez Ramalle's paper discusses the role played by common ground in the selection of connectives. Martín Zorraquino's contribution is concerned with the echoic use of the future tense, which has a concessive function and marks disagreement with the hearer's presupposition. The paper by Marcovecchio accounts for the evolution of interlocutor-oriented deixis (ahî) into epistemic stance markers. Finally, Meléndez Quero shows in his contribution how evaluative adverbs are being used to anticipate the emotional impact that negative news may have on the interlocutor.

\section{Proposed structure}

Barbara De Cock (Université Catholique de Louvain). Intersubjectivity in spoken Spanish interaction: a corpus study of informal language, TV-debate and parliamentary debate.

Anja Hennemann (Universität Potsdam). Pensar, no es siempre pensar: Las diferentes funciones de pienso (que).

Hilde Hanegreefs \& Eva González Melón (KU Leuven - Lessius). Percepción en discurso: efectos comunicativos de los marcadores "mira" and "a ver".

Catalina Fuentes Rodríguez (Universidad de Sevilla). Operadores de comentario y argumentación.

Teresa María Rodríguez Ramalle (Universidad Complutense de Madrid). Modalidad evidencial y estructura discursiva: el caso de tres marcadores consecutivos del español.

Maria Antonia Martín Zorraquino (Universidad de Zaragoza). Pragmagramática de la concesión en español: el tipo 'será suizo, pero es impuntual'.

Ana María Marcovecchio (Universidad de Buenos Aires). Por ahí / ni ahí o el desplazamiento desde el campo locativo al de la modalidad. 
Carlos Meléndez Quero (CNRS - Université de Nancy). La delimitación del significado de los adverbios evaluativos emotivos en términos de operaciones y de estrategias discursivas.

\section{References}

Aikhenvald, Y. Alexandra. 2004. Evidentiality. Oxford: Oxford University Press.

Athanasiadou, Angeliki, Costas Canakis \& Bert Cornillie (eds.). 2006. Subjectification: various paths to subjectivity. Cognitive Linguistics Research 31. Berlin: Mouton de Gruyter.

Bakhtin, Mikhail 1987. Problems of Dostoevski's Poetics. Minneapolis: University of Minnesota Press ,

Benveniste, Emile. 1966. De la subjectivité dans le langage. In : Emile Benveniste (ed.), Problèmes de linguistique générale, 258-266.Paris: Editions Gallimard.

Berqvist \& San Roque 2012. Complex perspective in epistemic marking: a workshop on the origins, motivations and definitions of intersubjective perspectives in grammar. 45th annual meeting of the Societas Linguistica Europaea (SLE). Stockholm University. September 2012.

Briz, Antonio. 1993. Los conectores pragmáticos en español coloquial (I): Su papel argumentativo. Contextos 6: 21-22: 145-188.

Bustos Tovar, José Jesús de (ed.). 2001. Lengua, discurso, texto. I Simposio Internacional de Análisis del Discurso. Madrid: Visor.

Coates, Jennifer. 1987. Epistemic modality and spoken discourse. Transactions of the Philological Society 85: 1. 110-131.

Cornillie, Bert \& Pietrandrea, Paula 2012. Modality at work: Cognitive, interactional and textual functions of modal markers. Special issue of the Journal of Pragmatics.

De Smet, Hendrik, \& Verstraete, Jean-Christophe. 2006. Coming to terms with subjectivity. Cognitive Linguistics 17(3): 365-92.

Domínguez García, Noemí. 2007. Conectores argumentativos en textos breves. Madrid: Arco Libros.

Du Bois, J.W. 2007. The stance triangle. In R. Englebretson (ed.) Stancetaking in discourse. Amsterdam: Benjamins, 139-182.

Englebretson, Robert (ed.). 2007. Stancetaking in Discourse. Subjectivity, Evaluation, Interaction. Amsterdam / Philadelphia: John Benjamins.

Evans, Nicholas. 2007. View with a view: towards a typology of multiple perspective. Berkeley Linguistics Society, 93-120.

Givón, Talmy. 1990. Syntax: A functional-typological introduction. Volume II. Amsterdam: John Benjamins.

Goffman, Erving. 1981. Forms of Talk. Philadelphia: University of Philadelphia Press.

Heritage, John. 2005. Cognition in discourse. In: Hedwig teMolder \& Jonathan Potter (eds.), Conversation and cognition, 184-202. Cambridge: Cambridge University Press. . 2007. Intersubjectivity and progressivity. In: N. J. Enfield \& Tanya Stivers (eds.), Person reference in interaction. Linguistic, cultural and social perspectives, 255-80. Cambridge: Cambridge University Press.

Jefferson, Gail. 1987. On exposed and embedded correction in conversation. In: Graham Button \& John R. E. Lee (eds.), Talk and social organization, 86-100. Clevedon: Multilingual Matters. 
Kärkkäinen, Elisabeth. 2003. Epistemic stance in English conversation. A description of its interactional functions, with a focus on I think. Amsterdam - Philadelphia: Amsterdam.

König, Ekkehard \& Siemund, Peter. 2007. Speech Act Distinctions in Grammar. In Timothy Shopen (ed.) Language Typology and Syntactic Description, vol. 1. Cambridge: Cambridge University Press.

Levinson, Stephen C., \& Enfield, Nick J. (Eds.). 2006. Roots of human sociality. Oxford, UK: Berg.

Lyons, John. 1977. Semantics vol. 2. Cambridge: Cambridge University Press.

Márquez Reiter, Rosina \& Placencia, María Elena (eds.). 2004. Current trends in the pragmatics of Spanish. Amsterdam/Philadelphia: John Benjamins Publishing Company.

Martín Zorraquino, María Antonia \& Montolío Durán, Estrella (eds.). 1988. Los marcadores del discurso: teoría y análisis. Madrid: Arco Libros.

Montolío Durán, Estrella. 2001. Conectores de la lengua escrita. Barcelona: Ariel.

Nuyts, Jan. 2001. Epistemic modality, language, and conceptualization: A cognitivepragmatic perspective. Amsterdam - Philadelphia: Benjamins.

Pons Bordería, Salvador. 1998. Conexión y conectores. Estudio de su relación en el registro informal de la lengua, Cuadernos de Filología, Anexo XXVII, Valencia: Universitat de València.

Portolés, José. 1995. "Diferencias gramaticales y pragmáticas entre los conectores discursivos pero, sin embargo y no obstante". Boletín de la Real Academia Española, 75. 231-269.

Schegloff, Emmanuel E. 1992. Repair after next turn: the last structurally provided defense of intersubjectivity in conversation. American Journal of Sociology 97(5): 1295-345.

Scheibmann, Joanne. 2002. Point of view and grammar. Structural patterns of subjectivity in American English conversation. Amsterdam - Philadelphia: John Benjamins.

Searle, John R. 1969. Speech Acts: An essay in the philosophy of language. Cambridge: Cambridge University Press.

Searle, John R. 1979. Meaning and Expression. Cambridge: Cambridge University Press

Simon-Vandenbergen, Anne-Marie \& Karin Aijmer. 2007. The Semantic Field of Modal Certainty. A Corpus-Based Study of English Adverbs. Berlin - New York: Mouton de Gruyter.

Traugott, Elisabeth Closs. 1989. On the rise of epistemic meanings in English: An example of subjectification in semantic change, Language 57: 33-65.

Traugott, Elisabeth Closs. 2003. From subjectification to intersubjectification. In: Raymond Hickey (ed.), Motives for language change, 124-39. Cambridge: Cambridge University Press.

Traugott, Elizabeth Closs \& Dasher, Richard B. 2002. Regularity in semantic change, Cambridge, Cambridge University Press.

Verhagen, Arie. 2005. Constructions of Intersubjectivity: Discourse, Syntax, and Cognition. Oxford: Oxford University Press.

Verhagen, Arie. 2008. Intersubjectivity and the architecture of the language system. In The Shared Mind: Perspectives on Intersubjectivity. Jordan Zlatev et al. (eds.).

Amsterdam: John Benjamins. Chapter 12.

Zlatev, Jordan \& Racine, Timothy P. \& Sinha, Chris \& Itkonen, Esa. 2008. (eds.) The Shared Mind: Perspectives on Intersubjectivity. Amsterdam: John Benjamins. 